Journal of Telenursing (JOTING)

Volume 2, Nomor 2, Desember 2020

e-ISSN: 2684-8988

p-ISSN: 2684-8996

DOI: https://doi.org/10.31539/joting.v2i2.1397

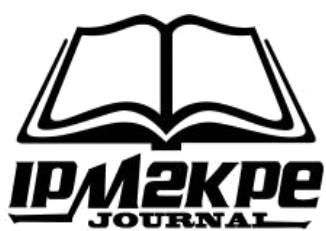

\title{
PENGALAMAN PASIEN ODHA DALAM ADAPTASI FISIOLOGIS
}

\author{
Juli Andri ${ }^{1}$, Agus Ramon ${ }^{2}$, Padila $^{3}$, Andry Sartika ${ }^{4}$, Eka Putriana $^{5}$ \\ Universitas Muhammadiyah Bengkulu ${ }^{1,2,3,4,5}$ \\ juli_andri0788@yahoo.co.id ${ }^{1}$
}

\begin{abstract}
ABSTRAK
Penelitian ini bertujuan untuk mengeksplorasi pengalaman pasien ODHA dalam adaptasi fisiologis di RSUD Dr. M. Yunus Bengkulu. Jenis Penelitian adalah penelitian kualitatif dengan metode survey dan wawancara mendalam (Indept Interview). Hasil Penelitian, aspek pengetahuan ketiga informan sudah memahami dan mengetahui tentang HIV/AIDS. Aspek masalah adaptasi fisiologis didapatkan berupa diare terus menerus, penerunan nafsu makan, penurunan berat badan yang secara drastis, mudah lelah apabila beraktivitas, insomia atau gangguan tidur, kulit gatal-gatal, infeksi pada kulit, mudah sakit (demam, flu dan batuk), nyeri-nyeri sendi, kesemutan, pelupa, penglihatan yang rabun, dan tidak mau terbuka dengan lingkungan sekitar. Aspek pengalaman ODHA dalam mengatasi masalah adaptasi fisiologis yaitu ODHA tidak hanya bergantung dengan obat ARV saja akan tetapi mereka menggunakan obat lain sesuai keluhan, dan menggunkan obat-obat herbal. Simpulan, ke tiga Informan memahami pengetahuan tentang HIV/AIDS, memiliki banyak masalah yang muncul pada adaptasi fisiologis, dan cara ODHA untuk mengatasi masalah adaptasi fisiologis yaitu dengan cara tradisional dan farmakologi.
\end{abstract}

Kata Kunci: Adaptasi Fisiologis, Pengalaman ODHA

\section{ABSTRACT}

This study aims to explore the experiences of ODHA patients in physiological adaptations in Dr. M. Yunus Bengkulu. This type of research is qualitative research with survey methods and in-depth interviews (In-depth Interview). The results showed that the knowledge aspect of the three informants understood and knew about HIV I AIDS. Elements of the problem of physiological adaptation are obtained in the form of continuous diarrhea, continued appetite, drastic weight loss, fatigue when on the move, insomnia or sleep disturbances, itchy skin, infection of the skin, uncomplicated illness (fever, flu, and cough), joint pains, tingling sensation, forgetfulness, low vision, and refusing to open up to the surrounding environment. The aspect of ODHA experience in overcoming the problem of physiological adaptation is that ODHA not only depends on $A R V$ drugs, but they use other medications according to complaints and use herbal medicines. In conclusion, the three informants understand HIV / AIDS, have many problems that arise in physiological adaptation, and how ODHA to overcome the problem of physiological adaptation, namely traditional and pharmacological ways.

Keywords: Physiological Adaptation, Experience of ODHA 


\section{PENDAHULUAN}

Penyakit Human Immunodeficiency Virus (HIV) merupakan penyakit infeksi penyebab kematian peringkat atas dengan angka kematian (mortalitas) dan angka kejadian penyakit (morbiditas) yang tinggi serta membutuhkan diagnosis dan terapi yang cukup lama (Padila, 2012). HIV merupakan virus yang menyerang sel darah putih (limfosit) di dalam tubuh yang mengakibatkan turunnya kekebalan tubuh manusia sehingga menyebabkan Aqciured Immunodeficiency Syndrome (AIDS) (Kemenkes RI, 2015). Penderita yang sudah positif HIV/AIDS biasanya disebut sebagai ODHA (orang dengan HIV/AIDS). Sampai saat ini belum ditemukan vaksin atau obat yang relatif efektif untuk AIDS sehingga menimbulkan keresahan di dunia (Widoyono, 2011). Penyakit HIV/AIDS ini merupakan masalah kesehatan masyarakat yang serius di seluruh dunia termasuk Indonesia (Yulianingsih, 2015).

Jumlah pederita HIV/AIDS Pada tahun 2015, tercatat ada sekitar 36,7 juta jiwa terinfeksi HIV dan 1,1 juta kematian akibat AIDS di seluruh dunia. Kawasan dengan angka kasus HIV dan AIDS terbanyak di dunia adalah kawasan Afrika. Dari jumlah penderita tersebut tergolong usia dari 20 tahun sampai 40 tahun. Penderita HIV/AIDS merupakan kalangan laki-laki (World Health Organization, 2016). Pada tahun 2016 ada sekitar 25,5 juta orang (hampir 75\% dari total HIV/AIDS di seluruh dunia) yang hidup dengan HIV di kawasan Afrika.

Sedangkan di Indonesia Jumlah kumulatif penderita HIV/AIDS pada umur >15 tahun pada tahun 2015 untuk jumlah HIV baru yaitu sebanyak 30.935 orang, pada tahun 2016 sebanyak 41.250 orang, pada tahun 2017 sebanyak 48.300 orang. Sedangkan kasus baru AIDS pada tahun 2015 yaitu 9.215 orang, pada tahun 2016 sebanyak 10.146 orang, pada tahun 2017 sebanyak 9.280 orang, maka dijumlahkan keseluruhan penderita HIV/AIDS pada tahun 2017 sebanyak 628.492 orang dengan jumlah infeksi baru sebanyak 46.357 orang dan kematian sebanyak 40.468 orang. Dari tahun ke tahun penderita HIV/AIDS cenderung meningkat, untuk golongan penderita HIV/AIDS cenderung banyak dari laki-laki dari pada permpuan (Profil Kesehatan Indonesia, 2017).

Jumlah penderita HIV/AIDS untuk kota Bengkulu pada tahun 2016 jumlah kematian HIV/AIDS sebanyak 19 orang. Pada tahun 2017 jumlah penderita HIV sebanyak 74 orang, untuk penderita AIDS sebanyak 18 orang, dan jumlah kematian sebanyak 4 orang. Sebagian besar penderita adalah laki-laki dan golongan umur penderita adalah 22-44 tahun (Dinkes Provinsi Bengkulu, 2017).

Orang dengan HIV AIDS (ODHA) sering dihadapkan pada kondisi yang rumit apakah harus mengungkapkan atau menyembunyikan kondisi penyakit yang sedang dialami. Menyembunyikan kondisi penyakit ini dapat mengakibatkan penderitaan batin yang dirasakan sangat menyiksa karena beban menjaga rahasia (Rouleau et al., 2012). Di sisi lain, mengungkapkan kondisi penyakit juga dapat menimbulkan permasalahan seperti penolakan (Chaudoir et al., 2011).

Masyarakat seringkali memberikan anggapan negatif bagi pasien ODHA, sehingga stigma negatif tersebut akan mempengaruhi ODHA dalam merespon terhadap adaptasi fisiologisnya. Penelitian yang dilakukan Maharani (2018) hasil penelitian menunjukkan bahwa masyarakat memberikan cap negatif terhadap ODHA sehingga cap negatif tersebut menyebabkan diskriminasi dalam masyarakat seperti pengucilan, penolakan, penghindaran. Proses pemberian label negatif dalam masyarakat tersebut terjadi karena keseharian dari penderita HIV, minimnya pengetahuan HIV/AIDS, perubahan fisik dan adanya provokator. 
Dari hasil wawancara, pasien mengatakan mudah lelah saat beraktivitas, demam yang secara tiba-tiba, pegal-pegal, nyeri otot dan sendi, mengalami sakit kepala secara tiba-tiba, diare yang terus menerus, nafsu makan menurun, penurunan berat badan, dan klien mengatakan hanya beraktivitas dirumah karena klien mudah kelelahan. Hasil observasi dari klien, kulit klien tampak ada ruam, klien tampak kurus, terlihat hitam disekitar bawah mata klien. Klien mengatakan dalam mengatasi masalah adaptasi Fisiologis klien hanya kebanyakan beraktivitas di rumah, pada saat demam klien hanya meminum obat biasa saja, saat nafsu makan menurun klien mengatakan cuma memakan yang disukai saja kadang-kadang hanya makan bubur atau buah. Klien juga mengatakan saat kondisi yang sangat-sangat lemah klien hanya berbaring di tempat tidur,meminum vitamin dan penambah stamina supaya bisa meningkatkan sistem kekebalan tubuh, akan tetapi tetap saja gampang sakit.

\section{METODE PENELITIAN}

Jenis penelitian ini adalah penelitian kualitatif dengan metode survey dan wawancara mendalam (Indept Interview) pada pasien ODHA dalam adaptasi fisiologis. Jenis penelitian ini dimaksudkan untuk mengembangkan teori dari fenomena sosial berdasarkan data yang diperoleh dari lapangan. Penelitian ini dilaksanakan di RSUD Dr. M.Yunus Bengkulu di unit PKT-VCT. Waktu penelitian yaitu pada bulan Mei 2019.

Instrumen penelitian dalam penelitian kualitatif adalah peneliti sendiri dengan melakukan wawancara mendalam (indepth interview) dengan menggunakan alat bantu rekam dan catatan hasil observasi. Informan dalam penelitian ini sebanyak 3 orang. Teknik pengambilan data dalam penelitian ini ditentukan sesuai prinsip penelitian kualitatif yaitu kesesuaian (approppriateness) dan kecukupan (adequacy) serta dengan pertimbangan sesuai kebutuhan penelitian. Sumber informasi dalam penelitian ini adalah pasien ODHA dalam adaptasi fisiologis. Informasi dalam penelitian ini ditentukan dengan teknik sampling, yaitu tehnik pengambilan informasi sumber data dengan pertimbangan tertentu, dimana informasi yang diambil dianggap paling tahu tentang apa yang kita harapkan dan dapat memberikan informasi yang berharga bagi penelitian. Kriteria informasi meliputi kriteria inklusi dan kriteria eksklusi, dimana kriteria tersebut menentukan dapat atau tidaknya informasi digunakan.

\section{HASIL PENELITIAN}

\section{Pengetahuan Mengenai Pengertian HIV/AIDS}

Hasil penelitian dari ketiga informan mengetahui apa itu HIV/AIDS, HIIV/AIDS yaitu virus yang menyerang kekebalan tubuh seperti yang dikemukakan oleh ketiga informan, berikut ungkapan dari informan :

HIV/AIDS itu virus...yang ibu tahu virus HIV/AIDS mengakibatkan apa ? "virus HIV/AIDS menyerang kekebalan tubuh jadi iya mudah sakit-sakit"

(Wawancara dengan informan 1 Ny. R pada tanggal 19 juni 2019).

Hasil penelitian dari ketiga informan mengetahui penyebab dari HIV/AIDS yaitu akibat berhubungan seksual dengan orang yang terkena HIV/AIDS, penggunaan jarum suntik yang tidak steril, lewat tranfusi darah oleh orang yang terkena HIV/AIDS seperti yang dikemukakan oleh ketiga informan sebagai berikut :

Penyebab nya bisa akibat berhubungan dengan orang terkena HIV/AIDS juga, biasanya juga dari suntikan.

(Wawancara dengan informan 1 Ny. R pada tanggal 19 juni 2019). 
Ditularkan melalui cairan mani, taranfusi darah, jarum suntik dan hubungan sek. (Wawancara dengan informan 2 Ny. F pada tanggal 19 juni 2019).

Hasil penelitian dari ketiga informan mengetahui cara penularan HIV/AIDS yaitu lewat hubungan seksul, jarum suntik, dan lewat tranfusi darah hal tersebut sama seperti yang di kemukakan oleh ketiga informan sebagai berikut :

Lewat hubungan seksual dengan orang yang terkena HIV/AIDS dan jarum suntik. Saya terlular HIVIAIDS itu dari suami..begini..suami saya itu kan seks nya sudah hiperseks sedangkan saya biasa aja tuh kan..jadi akibat itu suami saya jajan wanita lain..pernah tuk kan dek saya bukak isi tas kerja suami saya, saya terkejut isi nya itu kondom sama obat kuat..suami saya itu sudah lama sepertinya terkena HIV/AIDS itu tapi dia tidak mau jujur.

(Wawancara dengan informan 1 Ny. R pada tanggal 19 juni 2019).

\section{Pengetahuan Mengenai Cara Mencegah HIV/AIDS}

Hasil penelitian dari ketiga informan mengetahui cara mencegah dini HIV/AIDS yaitu berhubungan seksual yang aman, pola hidup yang sehat seperti yang diungkapakan oleh ketiga informan sebagai berikut :

Berhubungan yang aman, pola hidup yang sehat, dan tidak menggunakan jarum suntik yang bahaya saja yang saya tahu.

(Wawancara dengan informan 1 Ny. R pada tanggal 19 juni 2019).

\section{Pengetahuan Mengenai Pengobatan yang Pernah Dilakukan}

Hasil penelitian dari ketiga informan mengungkapakan obat yang mereka gunakan adalah obat ARV sebagai obat rutin dan tambahan obat sesuai dengan keluhan yang dialami, berikut ungkapan dari ketiga informan :

Pertama saya dibelikan anak saya PCO dan Hamazon obat herbal anak saya nyari di internet. Banyak obat yang gak cocok dengan saya jadi saya rutih berobat dari rumah sakit saja.

(Wawancara dengan informan 1 Ny. R pada tanggal 19 juni 2019).

Gak ada sih hanya pengobatan dari rumah sakit saja ARV.

(Wawancara dengan informan 2 Ny. F pada tanggal 19 juni 2019).

\section{Pengalaman ODHA dalam Mengatasi Masalah Adaptasi Fisiologis Oksigen}

Hasil penelitian didapatkan pengalaman ketiga informan mengatasi masalah oksigenasi yaitu dengan cara merubah pola kebiasaan. Adupun cara informan mengatasi masalah tersebut dengan cara berhenti merokok, merubah pola kebiasaan, berikut ungkapan dari ketiga informan :

Paling berobat ke dokter....gak ada obat lain kecuali beli di apotek...obat yang sring digunakan itu iya paling Activet kadang-kadang juga Flutamol..pas minum iya Alhamdulilah ada peerubahan. (Wawancara dengan informan $2 \mathrm{Ny}$. F pada tanggal 19 juni 2019).

\section{Nutrisi}

Hasil penelitian didapatkan pengalaman informan dalam mengatasi masalah nutrisi. Adapun cara yang dilakukan, makan-makanan yang disukai saja, minum obat $\mathrm{ARV}$, minum vitamin $\mathrm{C}$ dan vitamin-vitamin yang lain. menghindari makanan yang 
menggunkan micin dan memasak makanan dengan sendiri, berikut ungkapan dari ketiga informan :

Ya paling minum vitamin $C$ atau kadang-kadang juga curcuma gitu.

(Wawancara dengan informan 2 Ny. F pada tanggal 19 juni 2019).

\section{Eliminasi}

Hasil penelitian didapatkan pengalaman ketiga informan mengatasi masalah dengan cara minum obat ARV dan minum obat diare, berikut ungkapan dari ketiga informan :

Iya paling minum obat, periksa ke rumah sakit M. Yunus dikasih obat aja. kalau gak minum obat gak mau BAB, kalau gak minum obat gak BAK juga.

(Wawancara dengan informan 1 Ny. R pada tanggal 19 juni 2019).

\section{Aktivitas dan Istirahat}

Hasil penelitian didapatkan bahwa pengalaman ketiga informan dalam mengatasi masalah aktivitas dan istirahat. Adapun cara mengatasi masalah dengan cara aktivitas hanya banyak dirumah saja, minum obat rutin ARV dan obat tambahan sesuai keluhan. Pada saat tidak bisa tidur cara informan 1 mengatasi masalah tersebut dengan cara tradisional dengan cara dibekam pakai air hangat yang dimasukan ke dalam botol, sedangkan cara informan 2 dan 3 cara mereka supaya bisa tidur dengan cara nonton TV sama main HP, berikut ungkapan dari ketiga informan :

Kalau lagi lelah kayak gitu cuma istirahat dan tidur, nonton tv ujung-ujungnya juga nanti tertidur juga itu aja tempat tidur di kamar ada di depan tv di ruangan tamu ada.... supaya bisa tidur pas kulit lagi gatal-gatal Saya masukan air panas/hangat ke dalam botol terus saya bekam ke daerah yang gatal-gatal, jadi pas dilakukan itu gatal-gatal nya berkurng. Dan juga saya makan vitamin seperti sangobion, buahbuahan, sari kurma biar tidak terlalu ngedrop kayak gitu.

(Wawancara dengan informan 1 Ny. R pada tanggal 19 juni 2019).

\section{Proteksi/Perlindungan}

Hasil penelitian didapatkan pengalaman cara ketiga informan mengatasi masalahproteksi/perlindungan dengan cara, informan 1 mengatasi masalah gatal-gatal dengan cara dibekam pakai air hangat yang dimasukan didalam botol kedaerah yang gatal setelah itu baru bisa tidur dan gatal-gatal hilang. Sedengkan informan 2 dan 3 hanya minum obat gatal-gatal saja. Ketiga informan juga memiliki kesaman dengan cara apabila sakit/demam, flu dan batuk hanya bergantung dengan obat ARV dan obat lain sesuai keluhan yang dialami oleh ODHA, berikut ungkapan dari ketiga informan :

Iya tadi kalau kulit saya gatal-gatal, jalan satu-satu nya karena saya takut macammacam jadi saya bekam pakai air hangat, kadang-kadang juga saya minum obat gatal-gatal. Kuku saya gak biarkan panjang soalnya takut nanti saya garut jadi berdara semиa. Jadi saya sering menyiapak/masak air hangat... Kalau demam iya saya minum obat seperti paracetamol, kalau untuk menghindari suapaya gak batuk iya gak makan-makan yang berminyak. Dan saya pernah dek sikat gigi kan gak sengaja kena dsn luka jadi darah nya itu banyak benar saya langsung obati, jadi sikat gigi itu ada 2 macam sekarang.

(Wawancara dengan informan 1 Ny. R pada tanggal 19 juni 2019). 


\section{The Sense/Perasaan}

Hasil penelitian ditemukan cara pengalaman mengatasi masalah The sense/perasaan yaitu, memakai alat bantu kacamata, pada saat nyeri-nyeri minum obat ARV/obat tambahan sesuai dengan keluhan dan dipijit-pijit/diurut, hal tersebut dikemukakan oleh ketiga informan sebagai berikut :

Kalau pengelihatan saya kabur-kabur Iya kadang-kadang saya pakai kaca mata, beli di optik di prapto situ...kalau saya nyeri-nyeri, kesemutan dan keram Paling saya pijat pakai GPU, malam-malam saya olesi kaki sambil dipjit pakai GPU dan juga sering kaku-kaku dan juga nyeri nya itu pedih jadi saya gunakan GPU itu sama di pijit-pijit aja. Suami dulu juga kayak gitu.

(Wawancara dengan informan 1 Ny. R pada tanggal 19 juni 2019).

\section{Cairan dan Elektrolit}

Hasil penelitian dari ketiga informan memiliki bermacam-macam cara pengalaman mengatasi masalah cairan dan elektrolit yaitu apabila mersa kekeringan dan badan terasa bersisik-sisik maka minum air putih yang banyak dan mandi, hal tersebut sama seperti yang dikemukakan dari ketiga informan sebagai berikut :

Pas lagi kekurangan cairan dan tubuh terasa kering Jadi saya minum air putih terus. (Wawancara dengan informan 1 Ny. R pada tanggal 19 juni 2019).

\section{Fungsi Neurologi}

Hasil penenlitian dari ketiga informan memiliki bermacam-macam cara pengalaman mengatasi masalah fungsi neurologi. Adapun cara mengatasi masalah pelupa dengan cara mendekatkan barang disekitar, apabila nyeri-nyeri minum obatobatan dan di urut. Pada saat sakit kepala yang secara mendadak mminum obat penahan rasa sakit atau obat untuk mengurangi rasa sakit, hal tersebut sama seperti yang dikemukakan oleh ketiga informan sebagai berikut :

Saya kan pelupa jadi Paling saya masukan barang yang penting itu ke dalam tas semua...kalau mengalami kekakuan otot, kesemutan dan keram Iya paling saya olesi pakai GPU sambil dipikjit-pijit kan kadang-kadang juga saya minum obat. Sudah tu saya istirahtakan saja tidur-tiduran aja...kalau sakit kepala Iya kalau saya paling minum obat paracetamol aja.

(Wawancara dengan informan 1 Ny. R pada tanggal 19 juni 2019).

\section{Fungsi Endokrin}

Hasil penelitian dari ketiga informan tidak memiliki masalah hanya mudah sakit yang diakibtkan daya tahan tubuh yang menurun, berikut ungkapan dari ketiga informan:

Tidak ada masalah. Cuma gampang sakit saja..paling pas sakit cuma minum obat saja. (Wawancara dengan informan 1 Ny. R pada tanggal 19 juni 2019).

\section{Kurang Percaya Diri}

Dari hasil penelitian ketiga informan tertutup dengan lingkungan sekitar, tidak mau bersosialiasai dngan lingkungan, menutup diri, menutup status tentang penyakitnya dengan orang lain hanya keluarga yang mengetahui. Hal tersebut dikarenakan pasien ODHA tidak mau orang lain mengetahui tentang status penyakit mereka diketahui dikarenakan ODHA sangat sensitif apabila orang mengatahui status penyakitnya dan 
ODHA merasa apabila orang lain tahu tentang penyakit yang dialaminya maka orang lain akan menjauh dan merasa dikucilkan oleh masyarakat.

\section{PEMBAHASAN}

\section{Persepsi tentang HIV/AIDS Pengertian}

Berdasarkan hasil wawancara yang telah dilakukan terhadap beberapa informan mengenai persepsi mereka mengenai HIV/AIDS. Ketiaga informan menjawab hampir sama, yaitu HIV/AIDS itu virus yang menyerang kekebalan tubuh. Persepsi ini hampir sama dengan beberapa pengertian HIV/AIDS dari berbagai sumber antara lain : AIDS (Acquired Immunodeficiency Sydrom) dapat diartikan sebagai kumpulan gejala atau penyakit yang disebabkan oleh menurunnya sistem kekebalan tubuh akibat infeksi oleh virus HIV (Human Immunodeficiency Virus) yang termasuk famili retroviridae. AIDS merupakan tahap akhir dari infeksi HIV (Koes, 2013).

Sedangkan menurut Widoyono (2011) Acquired Immune Deficiency Syndrom (AIDS) adalah suatu kumpulan gejalah penyakit kerusakan sistem kekebalan tubuh, bukan penyakit bawaan tetapi didapat dari hasil penularan. Penyakit ini disebabkan oleh Human Immunodeficincy virus (HIV). Penyakit ini telah menjadi masalah intrnasional karena dalam waktu yang relatif singkat terjadi peningkatan jumlah pasien dan semakin melanda banyak negara. Sampai saat ini belum ditemukan vaksin atau obat yang relatif efektif untuk AIDS sehingga menimbulkan keresahan di dunia.

Penelitian yang dilakukan Priharwanti \& Raharjo (2017) diperoleh hasil bahwa sebagian besar informan dalam penelitian ini juga telah mempunyai tingkat pengetahuan yang cukup mengenai HIV dan bagaimana upaya untuk pencegahan dan pengobatannya, meskipun ada informan yang karena keinginan memiliki anak tidak lagi mengindahkan resikonya yang akan dihadapinya. Pada penelitian lain juga diperoleh hasil bahwa persepsi mereka terhadap HIV adalah penyakit menular dan beresiko pada kematian, tingkat pengetahuan terhadap virus HIV dan informasi mengenai HIV cukup tinggi dan mereka mendapatkan informasi tersebut sebagian besar dari kementrian kesehatan setempat (Egbo \& Chukwu, 2015). Penelitian yang dilakukan Martilova (2020) menunjukkan bahwa ada hubungan antara pengetahuan remaja dalam pencegahan terjadinya HIV/AIDS.

\section{Penyebab}

Berdasarkan hasil wawancara yang telah dilakukan terhadap beberapa informan megenai persepsi mereka tentang penyebab HIV/AIDS. Semua informan menjawab hampir sama, yaitu penyebab HIV/AIDS dari hubungan seksual yang berbahaya, dari jarum suntik dan dari tranfusi darah. Menurut Widoyono (2011) Penyakit ini disebabkan berhubungan seksual dengan orang yang terkena HIV/AIDS juga, akibat pemakaian jarum suntik yang tidak steril, tranfusi darah oleh orang yang positif dan ibu hamil yang positif terkena HIV/AIDS.

\section{Cara Penularan}

Berdasarkan hasil wawancara yang telah dilakukan terhadap beberapa informan mengenai cara peneularan HIV/AIDS semua informan ampir sama menjawab, yaitu lewat hubungan seksual, jarum suntik dan tranfusi darah. Menurut Widoyono (2011) yaitu penyakiti ini menular melaluai berbagai cara, antara lain melalui cairan tubuh seperti darah, cairan gentalita, dan ASI. Virus juga terdapat dalam saliva, air mata, dan 
urin (sangat rendah). HIV tidak dilaporkan terhadap dalam air mata dan keringat. Pria yang sudah disunat memiliki resiko HIV yang lebih kecil dibandingkan dengan pria yang tidak disunat. Selain melalui cairan tubuh, HIV juga ditularkan melalui : ibu hamil, jarum suntik, tranfusi darah, dan hubungan seksual. Cara penularan HIV/AIDS yang menonjol adalah melalui hubungan seks (heteroseks) dan penyalahgunaan NAPZA melalui suntik (IDU) (Juliansyah et al., 2020 ; Dinkes Sintang, 2017).

\section{Cara Pencegahan}

Berdasarkan hasil dari wawancara yang telah dilakukan didapatkan hasil wawancara dari semua informan hampir sama dalam menjelskan cara pencegaha HIV/AIDS yaitu berhubungan seksual dengan aman dan pola hidup sehat. Sementara itu menurut Widoyono (2011) pencegahan HIV/AIDS antara lain : menghindari hubungan seksual dengan penderita AIDS atau tersangka penderita AIDS, mencegah hubungan seksual dengan pasangan yang berganti-ganti atau dengan orang yang mempunyai banyak pasangan, menghindari hubungan seksual dengan pecandu narkotika obat suntik, melarang orang-orang yang termasuk ke dalam kelompok berisiko tinggi untuk melakukan donor darah, memberikan tranfusi darah hanya untuk pasien yang benarbenar memerlukan, dan memastikan sterilitas alat suntik.

\section{Pengobatan}

Berdasarkan hasil dari wawancara yang telah dilakukan didapatkan dari penjelasan informan hampir semua informan menjawab hanya menggunakan obat dari rumah sakit dan ada 1 informan sebelum akses ke obat HIV/AIDS (ARV) menggunakan obat herbal seperti PCO dan Hamazon obat herbal. Sementara itu menurut widoyono (2011) pengobatan dengan terapi anti-retroviral therapy (ART) dapat dimulai pada penderita dengan syarat: Dengan/ada fasilitas pemeriksaan CD4. Stadium IV, tanpa melihat jumlah CD4. Stadium III, dengan jumlah CD4 $<350 / \mathrm{mm}$. Stadium I atau II, dengan jumlah CD4 $<200 / \mathrm{mm}$. Tanpa pemeriksaan CD4 Stadium IV, tanpa melihat jumlah limfosit total. Stadium III, tanpa melihat jumlah limfosit total. Stadium II, dengan jumlah limfosit total $<1200 / \mathrm{mm}$.

\section{Masalah Adaptasi Fisiologis \\ Oksigenasi}

Berdasarkan hasil wawancara dari beberapa informan menjelaskan tentang oksiegenasi kadang-kadang mengalami masalah seperti batuk-batuk karena merokok dan pernah mengalami sesak nafas pada saat dulu sebelum akses ke obat ARV. Sedangan menurut Widoyono (2011) pada pasien HIV/AIDS mengalami infeksi saluran nafas bagian atas yang berulang.

Penderita AIDS pada mulanya hanya memperlihatkan tanda-tanda dan gejala yang tidak khas seperti demam, menggigil, batuk nonproduktif, napas pendek, dispneu dan kadang-kadang nyeri dada. Kosentrasi oksigen dalam darah arterial pada pada pasien yang bernapas dengan udara dalam ruangan dapat mengalami penurunan yang ringan; keadaan ini menunjukan keadaan hipoksemia minimal (Smeltzer, 2013). 


\section{Nutrisi}

Dari hasil wawancara dari informan mengatakan adanya masalah di nutrisi seperti penurunan berat badan yang terus, berkurangnya nafsu makan dan banyak makanan yang tidak disukai semenjak sakit.

Smeltzer (2013) menyatakan bahwa tanda dan gejala pada pasien AIDS antara lain hilangnya selera makan, mual,munta,vomitus, kandidiasis oral, serta esofagus, dan diare kronis. Bagi pasien AIDS, diare dapat membawah akibat yang serius sehubungan dengan terjadinya penurunan berat badan yang nyata (lebih dari $10 \%$ berat badan), gangguan keseimbangan cairan dan elektrolit, ekskoriasis kulit perinatal, kelemahan dan ketidak mampuan untuk nmelaksanakan kegiatan yang biasa dilakukan dalam kehidupan sehari-hari.

Pasien dengan HIV/AIDS sangat membutuhkan vitamin dan mineral dengan jumlah yang lebih banayk dari biasanya diperoleh dalam makanan sehari-hari. HIV menyebabkan hilangnya nafsu makan dan gangguan penyerapan nutrien hal ini berhubungan dengan menurunnya atau habisnya cadangan vitamin dan mineral dalam tubuh. Defisiensi vitamin dan mineral pada ODHA dimulai sejak masih stadium dini. Walaupun jumlah makanan ODHA sudah cukup dan berimbang seperti orang sehat, tetapi akan tetap terjadi defisensi vitamin dan mineral (Nursalam, 2011).

\section{Eliminasi}

Berdasarkan hasil wawancara didapatkan dari semua informan mengatakan adanya masalah di Eliminasi seperti meningkatnya jumlah BAK. Informan juga mengatakan jika tidak minum obat makan tidak mau BAK. Eliminasi yaitu ekskresi hasil dari metabolisme dari instestinal dan ginjal. Pada pasien ODHA mengalami perubahan frekuensi berkemih, konstipasi, diare, dan lain-lain (Nursalam, 2011).

\section{Aktivitas dan Istirahat}

Berdasarkan hasil wawancara didapatkan dari semua informan mengatakan adanya masalah di aktivitas dan istirahat, seperti mudah lelah, capek, aktivitas terbatas karena sakit, dan mengalami gangguan tidur pada saat malam hari. Selain itu, proses tidur dapat memperbaiki berbagai sel dalam tubuh. Fisiologis tidur merupakan pengaturan kegiatan tidur oleh adanya hubungan mekanisme sereberal yang secara bergantian untuk mengaktifitaskan dan menekan pusat otak agar dapat tidur dan bangun.

Salah satu aktivitas tidur ini diatur oleh sistem pengaktivitasan retikularis yang merupakan sistem yang mengatur seluruh tingkatan kegiatan susunan saraf pusat termasuk pengaturan kewaspadaan dan tidur. Pusat pengaturan aktivitas kewaspadaan dan tidur terletak dalam mesensefalon dan bagian atas pons. Selain itu, reticular activating system (RAS) dapat memebrikan rangsangan visual, pendengaran, nyeri, dan perabaan juga dapat menerima stimulasi dari korteks serebri termasuk rangsangan emosi dan proses pikir. Kebutuhan kesimbangan aktivitas fisik dan istirahat yang digunakan untuk mengoptimalkan fungsi fisiologis dalam memperbaiki dan memulihkan semua komponen-komponen tubuh.

\section{Proteksi/Perlindungan}

Dari hasil wawancara dengan informan semua informan mengatakan mengalami masalah proteksi/perlindungan yaitu mengalami kulit infeksi, kulit kering-kering, mudah sakit dan mudah mengalami flu dan batuk. Sebagai dasar defens tubuh termasuk 
proses imunitas dan struktur integumen (kulit, rambut dan kuku) dimana hal penting sebagai fungsi proteksi dari infeksi, trauma dan perubahan suhu.

\section{The Sense/Perasaan}

Berdasarkan hasil wawancara dengan semua informan mengatakan mengalami masalah penelihatan dan informan ke 2 juga mengatakan juga mengalami masalah pendengaran. Semua informan juga mengatakan memiliki masalah nyeri-nyeri. Dari hasil wawancara juga informan menjelskan dari semua informan belum mau bukak ststus kemasyarakat tentang penyakit nya. Hanya anggota keluarga yang mengetahui tentang penyakit nya.

Sitgma sosial dapat memperparah depresi dan pandangan yang negatif tentang harga diri pasien. Diskriminasi terhadap orang yang terinfeksi HIV, misalnya penolakan berkerja dan hidup serumah juga akan berpengaruh terhadap kondisi kesehatan. Bagi pasien homoseksual, penggunan obat-obat narkotika akan berakibat terhadap kurangnya dukungan sosial, hal ini akan memperparah stres pasien. Terjadinya waktu yang lama terhadap respons psikologis mulai penolakan, marah-marah, tawar menawar, dan depresi berakibat terhadap keterlambatan upaya pencegahan dan pengobatan. Pasien akhirnya mengonsumsi obat-obat terlarang untuk menghilangkan stress yang dialami (Nursalam, 2011).

Sejalan dengan penelitian yang dilakukan Amalia et al., (2018) menunjukkan bahwa respon psikologis yang terjadi pada pasien ODHS ketika dinyatakan positif terinfeksi HIV/AIDS antara lain keinginan bunuh diri, rasa sedih, pemakaian narkoba bertambah.

\section{Cairan dan Elektrolit}

Berdasarkan hasil wawancara dari ke tiga informan mengatkan memiliki masalah kekurangan cairan dan elektolit seperti kulit kering-kering, merasa tubuh nya kering bersisik-sisik. Elektrolit terdapat pada seluruh cairan tubuh. Cairan tubuh mengandung oksigen, nutrien, dan sisa metabolisme, seperti karbondioksida, yang semuanya disebut dengan ion.

Gangguan cairan dan elektrolit sangat umum pada periode perioperatif. Cairan intravena dengan jumlah yang besar sering diperlukan untuk memperbaiki defisit cairan dan mengkompensasi kehilangan darah selama operasi. Cairan dan elektrolit di dalam tubuh merupakan satu kesatuan yang tidak dapat terpisahkan. Komposisi cairan dan elektrolit di dalam tubuh diatur sedemikan rupa agar keseimbangan fungsi organ vital dapat dipertahankan (Mangku \& Senapathi, 2010; Rashida \& Aryasa, 2017 ). Gangguan besar dalam keseimbangan cairan dan elektrolit dapat dengan cepat mengubah kardiovaskular, saraf, dan fungsi neuromuskular, dan penyedia anestesi harus memiliki pemahaman yang jelas air normal dan elektrolit fisiologi (Butterworth et al., 2013).

\section{Fungsi Neurologi}

Berdasarkan hasil wawancara ke tiga informan didapatkan hasil informan mengatakan mengalami masalah neurologi seperti mengalami mengingat sesuatu, kelemahan otot, kesemutan dan sering mengalami sakit kepala secara tiba-tiba. Sedangkan dari konsep teori hubungan-hubungan neurologis merupakan bagian integral dari regulator merupakan bagian integeral dari regulator koping mekanisme sesorang. 
Manifestasi dini mencakup gangguan daya ingat, sakit kepala, kesulitan berkonsentrasi, konfusi progresif, pelambatan psikomotorik, apatis dan ataksia. Stadium lanjut mencakup gangguan kognitif global kelambatan dalam respon verbal, gangguan paraperesis spastik, psikologis, halusinasi, termor, intenkontenensia, serangan kejang, mutisme dan kematian. Kelemahan neurologik lainnya berupa neuropati perifer yang berhubungan dengan HIV diperkirakan merupakan kelainan demilinisasi dengan disertai rasa nyeri serta mati ras pada ekstremitas, kelemahan, penurunan refleks tendon yang dalam, hipotensi ortotastik dan impotensi (Smeltzer, 2013).

\section{Fungsi Endokrin}

Hasil dari wawancara ke tiga informan didapatkan hanya ada masalah pertumubuhan ke tiga informan menjelskan kalau masalah pertumbuhan hanya mudah sakit, mudah lelah dan capek.

Pasien ODHA masih harus dilakukan pemantauan apakah sistem endokrin berfrfungsi secara maksimal. Pemakaian obat-obata antiretroviral pada pasien ODHA perlu perhatian khusus, salah satunya monitoring fungsi hati. Monitoring fungsi hati dilakukan dengan memantau SGOT dan SGPT, untuk melihat terjadinya tingkat toksisitas yang terjadi pada hati yang berpotensi mengancam jiwa (Pathania et al., 2017; Alamsyah et al., 2020).

\section{Pengalaman Pasien ODHA dalam Mengatasi masalah Adaptasi Fisiologis Oksigenasi}

Berdasarkan hasil wawancara dari ketiga informan di dapatkan hasil informan mengatakn pada oksigensi tidak mengalami masalah pernafasan paling-paling Cuma batuk, cara pasien mengatasi masalah tersebut juga hanya berhenti merokok dan untuk informan 1 mengatakan cukup menghindari makanan yang bersifat berminyak. Menurut konsep teori Nursalam (2011) jika kebutuhan makanan yang tidak dipenuhi dalam sehari dapat membuat pasien menjadi lemah sehingga perlu diberikan makanan tambahan dalam bentuk formula. Makanan dapat diberikan dalam posisi pasien setengah tidur agar asupan oksigen ke paru-paru lebih optimal.

\section{Nutrisi}

Berdasarkan hasil dari wawancara dari ke tiga informan dalam pengalaman informan dalam mengahadapi masalah pada nutrisi ke tiga informan mengatakan dalam mengatasi diare yang sering tiba-tiba muncul dengan cara minum obat dari apotek. Dan cara ketiga informan dalam mengatasi masalah menurun nya nafsu makan dari ketiga informan menjelaskan memakan makanan yang disukai, meminum vitamin dan buahbuahan. Dari konsep teori menurut Nursalam (2011) pasien HIV pada umumnya mengalami penurunan nafsu makan. Hal ini bisa disebabkan karena pengaruh obat ARV dan kesulitan menelan akibat infeksi jamur kandida pada mulut. Untuk mengatasi anoreksia, pasien harus tetap makan meskipun tidak berselera, karena cara terbaik untuk meningkatkan nafsu makan adalah dengan makan.

Berdasarkan hasil wawancara dari ketiga informan mengatakan pengalaman cara megatasi masalah eliminasi yaitu minum obat dari apotek dan minum obat herbal. Meningkatnya jumlah berkemih atau BAK dikarenakan efek dari obat AVR. Konsep teori menurut Nursalam (2011) efek samping obat jangka pendek adalah : mual, muntah, diare, sakit kepala, lesu, dan susah tidur. Efek samping ini berbeda-beda pada setiap orang, jarang pasien mengalami semua efek samping tersebut. Efek samping 
jangka pendek terjadi segera setelah minum obat dan berkurang setelah beberapa minggu. Selama beberapa minggu penggunaan ARV, diperbolehkan minum obat lain untuk mengurangi efek samping. Efek samping obat jangka panjang ARV belum banyak diketahui. Efek samping pada wanita lebih berat dari pada laki-laki, salah satu cara mengatasi nya adalah dengan menggunakan dosis yang lebih kecil.

\section{Aktivitas dan Istirahat}

Berdasarkan hasil wawancara dari ke tiga informan didapatkan pengalaman cara informan menghadapi masalah aktivitas dan istirahat dengan cara istirahat saja di rumah, minum vitamin dan makan buah dan sayuran yang cukup. Sedangkan menurut teori menurut Nursalam (2011) defisiensi vitamin dan mineral pada pasien ODHA sudah dimulai sejak stadium awal. Walawpun jumlah makanan ODHA sudah cukup dan berimbang seperti orang sehat, tetapi ODHA akan tetap mengalami defisiensi vitamin dan mineral. Selain mengonsumsi makanan dalam jumlah yang tinggi, parah ODHA juga harus mengonsumsi suplemen atau zat gizi tambahan. Pemberian zat gizi tambahan bertujuan agar badan ODHA tidak bertambah akibat Defisiensi vitamin dan mineral yang biasa mereka alami.

\section{Proteksi/perlindungan}

Berdasarkan hasil wawancara dari ketiga informan, mengatakan pengalaman informan dalam menghadapi masalah proteksi/perlindungan dengan cara minum obat oral maupaun obat salap dan untuk informan 1 juga menggunakan air panas untuk membuat atau ditempelkan pakai botaol Aqua di tempat yang gatal-gatal supaya gatalgatal berkurang. Ketiga informan mengatakan hanya minum obat pada saat sakit dan flu batuk. Konsep teori menurut Nursalam (2011) dalam tubuh ODHA, partikel virus akan bergabung dengan DNA sel pasien, sehingga orang yang terinfeksi HIV seumur hidup akan tetap terinfeksi. Sebagian pasien memeperlihatkan gejalah tidak khas infeksi seperti demam, nyeri menelan, pembengkakan kelenjar getah bening, ruam, diare, dan batuk pada 3-6 minggu setelah infeksi. Jadi walaupun pasien minum obat ARV dan meminum obat lain itu bersifat untuk menenangkan atau kata lain itu memeperlambat progresivitas penyakit dan dapat memperpanjang daya tahan tubuh (Widoyono, 2011).

\section{The Sense/Perasaan}

Berdasarkan hasil wawancara dari ketiga informan mengatakn pengalaman informan dalam mengatasi masalah pada The sense/perasaan dengan cara menggunakan alat bantu kaca mata, pada saat nyeri informan juga minum obat, dipijit. Untuk status ke masyarakat ketiga informan belum membukak ststus tentang penyakit nya dengan orang lain. Peran perawatan pasien terinfeksi HIV adalah melaksanakan pendekatan Asuhan keperawatan agar pasien dapat beradaptasi dengan cepat.

Peran tersebut meliputi: memfasilitasi strategi koping dan dukungan sosial. Melalui sistem limbik dan korteks serebri diharapkan pasien akan mempunyai respons adaptif yang positif. Dari respons penerimaan diri, setelah pasien mendapatkan pembelajaran maka persepsi pasien akan menjadi positif, koping positif, dan akhirnya perilaku pasien dalam perawatan menjadi positif. Dari respons sosial, diharapkan pasien mempunyai koping yang konstruktif sehingga kecemasan berkurang. Penurunan kecemasan tersebut akan berdampak terhadap intraksi sosial yang positif, baik dengan keluarga, teman, tetangga, dan masyarakat (Nursalam, 2011). 


\section{Cairan dan Elektrolit}

Berdasarkan hasil wawancara dari ketiga informan mengatakan pengalaman cara mengatasi masalah cairan dan elektrolit yaitu dengan cara minum air putih yang banyak dan mandi. Dan informan mengatakan tidak meminum, minuman lain selain air putih. Dari konsep teori Nursalam (2011) air harus dimasak sampai mendidih atau air mineral dalam kemasan/botol. Sedangkan buah hujau dan masam, kopi, teh, dan alkohol yang memperburuk dehidrasi serta makanan yang terlalu gurih dan mengandung banyak gas.

\section{Fungsi Neurologi}

Berdasarkan hasil wawancara dari ketiga informan mengatakan pengalaman cara mereka menghadapi masalah dalam fungsi Neurologi yaitu meletakan barng-barang yang berharga ditempat yang sering digunakan. Informan juga mengatakan meminum obat pada saat sakit kepala dan kelemahan otot lain nya. Konsep teori menurut Nursalam (2011) keluhan seperti mual, muntah, diare, sakit kepala, lesu dan susah tidur merupakan efek samping obat jangka pendek. Fek samping terjadi segera setelah minum obat dan berkurang setelah beberapa minggu. Selama beberapa minggu penggunaan ARV, diperbolehkan minum obat lain untuk mengurangi efek samping.

\section{Fungsi Endokrin}

Dari Hasil wawancara kepada informan tidak ditemukan masalah pada sistem endokrin yang lebih lanjut, hanya masalah pertumbuhan dikarenakaan daya tahan tubuh sudah menurun, jadi informan mengatkan mudah sakit dan lelah.

Pasien ODHA masih harus dilakukan pemantauan apakah sistem endokrin berfrfungsi secara maksimal. Pemakaian obat-obata antiretroviral pada pasien ODHA perlu perhatian khusus, salah satunya monitoring fungsi hati. Monitoring fungsi hati dilakukan dengan memantau SGOT dan SGPT, untuk melihat terjadinya tingkat toksisitas yang terjadi pada hati yang berpotensi mengancam jiwa (Pathania et al., 2017; Alamsyah et al., 2020).

\section{SIMPULAN}

Pada aspek pengetahuan ketiga informan sudah mengetahui definisi HIV/AIDS, penyebab, cara penularan, cara pencegahan dini, dan pengobatan yang digunakan.

Pada aspek masalah-masalah yang muncul oada adaptasi fisiologis dari ketiga informan memiliki banyak masalah seperti batuk batuk, diare terus menerus, penurunan nafsu makan, penuruanan berat badan yang secara drastis, mudah lelah apabila beraktivitas, Insomia atau gangguan tidur, kulit gatal-gatal, infeksi pada kulit, mudah sakit (demam, flu dan batuk), nyeri-nyeri sendi, kesemutan, pelupa, pengelihatan yang rabun, dan tidak mau terbuka dengan lingkungan sekitar.

Pada aspek pengalaman ODHA dalam mengatasi masalah adaptasi fisiologis dari ketiga informan dalam mengatasi masalah adaptasi fisiologis yaitu dengan cara tradisional dan farmakologi. Dari ketiga informan 75\% hanya beraktivitas di rumah, dan tidak berani melakukan aktifitas yang berat. Dari ketiga informan tidak mau membukak ststus tentang penyakit yang mereka derita pada orang lain. Tertutup, tidak mau bersosialisai dengan lingkungan sekitar.

Dengan adanya masalah adaptasi fisiologis ini dari ketiga informan bukan hanya bergantung pada obat rutin saja tetapi obat yang lain juga sesuai dengan keluhan yang diraskan oleh ODHA. 


\section{SARAN}

Bagi masyarakat terutama yang memiliki anak yang masih remaja tolong dijaga anak nya jangan sampai terjerumus ke pergaulan yang akan merusak generasi ini, kalau sudah terkena HIV/AIDS maka tidak ada 1 pun obat yang bisa membuat sembuh melainkan hanya ada obat yang cuma memberikan efek mengurangi rasa sakit tetapi tidak kan menghilangkan penyakit tersebut.

\section{DAFTAR PUSTAKA}

Alamsyah, M. A. B. O., Rukmi, R., \& Rahmayani, F. (2020). Hubungan Lama Terapi Antiretroviral (ARV) dengan Kadar Serum Glutamic Oxsaloasetic Transminase (SGOT) dan Serum Glutamic Pyruvic Transminase (SGPT) Anak dengan HIV/AIDS d Rumah Sakit Abdul Moeloek. Skripsi. Universitas Lampung

Amalia, R., Sumartini, S., \& Sulastri, A. (2018). Gambaran Perubahan Psikososial dan Sistem Pendukung pada Orang dengan HIV/AIDS (ODHA) di Rumah Cemara Gegerkalong Bandung. Jurnal Pendidikan Keperawatan Indonesia, 4(1), 77-85. DOI: $10.17509 /$ jpki.v4i1.12346

Butterworth, J. F., Mackey, D. C., \& Wasnick, J. D. (2013). Management of Patients with Fluid and Electrolyte Disturbances. Morgan \& Mikhail's Clinical Anesthesiology 5th ed. New York: Mc-Graw Hill

Chaudoir, S. R., Fisher, J. D., \& Simoni, J. M. (2011). Understanding HIV Disclosure: A Review and Application of the Sisclosure Processes Model. Social Science \& Medicine, 72(10), 1618- 1629

Dinkes Provinsi Bengkulu. (2017). Profil Kesehatan Provinsi Bengkulu Tahun 2016

Egbo, E., \& Chukwu, V. A. (2015). Perception and Awareness of Hiv/Aids among Women Farmers in Ebonyi State Nigeria: Need For Counselling and Voluntary Testing. British Journal of Education, 3(5), 7-20

Gusti, R. P. (2015). Studi Fenomenologi Pengalaman Orang HIV/AIDS (ODHA) dalam Mendapatkan Dukungan Keluarga di Yayasan Lentera Minangkabau Support Padang. Ners Jurnal Keperawatan, 11(1), 22-31

Juliansyah, E., Maretalinia, M., \& Suyitno, S. (2020). Pengaruh Penyuluhan HIV/AIDS terhadap Pengetahuan dan Sikap Siswa SMA Negeri 1 Sepauk Kabupaten Sintang. Visikes, 19(1), 152-166. https://publikasi.dinus.ac.id/index.php/visikes

Kementerian Kesehatan RI. (2017). Profil Kesehatan Indonesia Tahun 2017

Kementrian Kesehatan RI. (2015). Konseling dan Tes HIV atas Inisiasi Petugas Kesehatan. Direktorat Jendral Pengendalian Penyakit dan Penyehatan Lingkungan

Koes, I. (2013). Mikrobiologis Medis. Bandung: Alfabeta

Maharani, I. (2018). Cap Orang dengan HIV dan AIDS (ODHA) Studi Sosiologi Kualitatif tentang Stigma. Universitas Airlangga

Mangku, G., \& Senapathi, T. G. A. (2010). Keseimbangan Cairan dan Elektrolit. dalam Buku Ajar Ilmu Anestesia dan Reanimasi. Jakarta: Indeks

Martilova, D. (2020). Faktor yang Mempengaruhi Pengetahuan Remaja dalam Pencegahan HIV/AIDS di SMA N 7 Kota Pekanbaru. Jomis (Journal of Midwifery Science), 4(1), 63-68

Nursalam, K. (2011). Asuhan Keperawatan pada Pasien Terinfeksi HIV/AIDS. Jakarta: Salemba Medika

Padila, P. (2012). Buku Ajar Keperawatan Medikal Bedah. Yogyakarta: Nuha Medika 
Pathania, S. M., Kaur, S. L. N., Kumar, M. S., Sshindran, A. C. V. K., \& Putri, B. P. (2017). A Crossectional Study of Liver Function Test in HIV Infected Person in Western India. Medical Journal Armed Force India, 73, 23-28

Priharwanti, A., \& Raharjo, B. B. (2017). Problem Focusd Coping Penderita HIV Positif. Public Heatlh Perspective Journal, 2(2), 131-139

Rashida, D., \& Aryasa, T. (2017). Gangguan Cairan dan Elektrolit. Universitas Udayana

Rouleau, G., Côté, J., \& Cara, C. (2012). Disclosure Experience in a Convenience Sample of Quebec-Born Women Living with HIV: A Phenomenological Study. BMC Women's Health, 12(37), 1-11. doi:10.1186/1472-6874-12-37

Smeltzer, S. C., \& Bare, B. G. (2013). Buku Ajar Keperawatan Medikal Bedah Brunner \& Suddarth, edisi 8. Jakarta: EGC

Widoyono, W. (2011). Penyakit Tropis (Epidemologi, Penularan, Pencegahan \& Pemberantasan). Jakarta: Erlangga

Yulianingsih, E. (2015). Faktor-Faktor yang Berhubungan dengan Tindakan Berisiko Tertular HIV/AIDS pada Siswa SMA Negeri di Kota Gorontalo. JIKMU, 5(4) 